\title{
Preliminary Investigation on Production of Biogas from Domestic Sewage
}

\author{
Kwasi-Effah C. Collins ${ }^{1}$, Ebunilo O. Patrick ${ }^{1}$, Ogbeide O. Osarobo ${ }^{2}$ \\ ${ }^{1}$ Department of Mechanical Engineering, University of Benin, Benin City, Nigeria \\ ${ }^{2}$ Department of Production Engineering, University of Benin, Benin City, Nigeria
}

Email address:

collinshicent@yahoo.com (Kwasi-Effah C. Collins)

\section{To cite this article:}

Kwasi-Effah C. Collins, Ebunilo O. Patrick, Ogbeide O. Osarobo. Preliminary Investigation on Production of Biogas from Domestic Sewage. International Journal of Mechanical Engineering and Applications. Vol. 5, No. 3, 2017, pp. 182-185.

doi: 10.11648/j.ijmea.20170503.17

Received: February 3, 2017; Accepted: May 5, 2017; Published: June 27, 2017

\begin{abstract}
A domestic biogas digester was used to test the concept of controlled anaerobic digestion. A mixture of $20 \mathrm{~kg}$ cow dong, $4 \mathrm{~kg}$ of water hyacinth, and $8 \mathrm{~kg}$ of domestic waste, was used to run the test. Result showed that a reasonable amount of biogas is generated on the second day of the test period. However, during the $5^{\text {th }}$ and $7^{\text {th }}$ day of the 10 days test period, biogas production was at its peak. The design is simple and easy to use. This design is capable of enabling the layman grasp the function and theory behind each component of the design with only a small amount of guidance. The idea here is to encourage people looking at the design to think and understand the requirements of controlled anaerobic digestion and the continuous flow model.
\end{abstract}

Keywords: Biogas, Renewable Energy, Anaerobic Digestion, Domestic Digester, Mixture, Production

\section{Introduction}

Biogas is a product of the natural decomposition of any organic substance of animal or plant origin due to the activity of anaerobic bacteria. It has a composition of about $65 \%$ methane $\left(\mathrm{CH}_{4}\right)$ and $35 \%$ carbon dioxide $\left(\mathrm{CO}_{2}\right)$ [1]. As a result of biogas technology, organic wastes like poultry droppings, food waste cow manure e.t.c are now seen as a means of solving energy problems [2]. Biogas technology has become an attractive alternative in developed and developing countries as the renewable fuel serves several policy priorities, ranging from increased domestic energy production to the reduction of greenhouse gases and more efficient waste treatment [3].

Biogas can be compressed, the same way natural gas is compressed to $\mathrm{CNG}$, and can be used for various applications including various heat engines and absorption refrigeration system. For instance, In the UK, biogas is estimated to have the potential to replace around $17 \%$ of vehicle fuel. It qualifies for renewable energy subsidies in some parts of the world. Biogas can be cleaned and upgraded to natural gas standards, when it becomes bio-methane. Biogas is considered to be a renewable resource because its production-and-use cycle is continuous, and it generates no net carbon dioxide. Organic material grows, is converted and used and then regrows in a continually repeating cycle. From a carbon perspective, as much carbon dioxide is absorbed from the atmosphere in the growth of the primary bioresource as is released when the material is ultimately converted to energy.

Industrialization and growth rate of a country depends on the availability and utilization of energy in that country [4]. The increasing worldwide awareness and concern about the environmental impact of fossil fuels coupled with the skyrocketing price of oil have learnt enormous weight to switch into renewable energy sources [5]. Nigeria is however yet to fully develop the use of renewable source such as biogas [6].

Gasification as a technology has been used commercially in different parts of the world. For instance, in 1990, China built more than 70 biogas system for the household cooking gas. Each of the system has an average gas delivery of $200-$ $400 \mathrm{~m}^{3}$ /hour to 1600 families [7]. In India, gasification is a choice method for electricity generation [8]. While in Finland; the Kymijarvi power plant of Ladhen Lampovoima 
produces electric power (167MW) and district heat (240MW) using gasification techniques [9].

In Nigeria, there is almost a small library of information on the utilization of organic waste in terms of how to design a cost effective domestic biogas digester. However, this bit of information doesn't seem to be reaching the average intensive farmer with some interest in biogas production. Thus, there could be a number of possible reasons for this including the capital cost of setting up an anaerobic digester project, lack of working models and basic ideas. This paper aims to identify key aspects of the biogas design and to develop a small scale working prototype possibly suited to operate in homes and on the average farm.

The processes involved in biogas production undergo distinct phases. During each phase, various microorganisms and a range of enzymes work symbiotically [10]. The hydrolysis process, carbohydrates are broken down into simple sugars, proteins into amino acids, and fats into fatty acids. The products of the hydrolysis undergo an acidogenic process (acidogenesis) where organic acids and low alcohols are produced. The subsequent acetogenic process leads to the production of methane. The products of the acidogenic process are converted into acetic acid, carbon dioxide and hydrogen, which are the compounds required for the methanogenic process (methanogenesis). If the process is well balanced, these phases are synchronized. The flow process involved in the conversion of fermented substrate to biogas is shown in the flow chart of Figure 1. From the flow chart, hydrolytic bacteria acts on complex organic compounds like carbohydrates and proteins which are then broken down into simple organic compounds. Acidogenic bacteria will then act on these simples compounds and break them into organic acids and alcohol. Finally, methanogenic bacteria will act on the organic acid thus, the expected methane gas is produced.

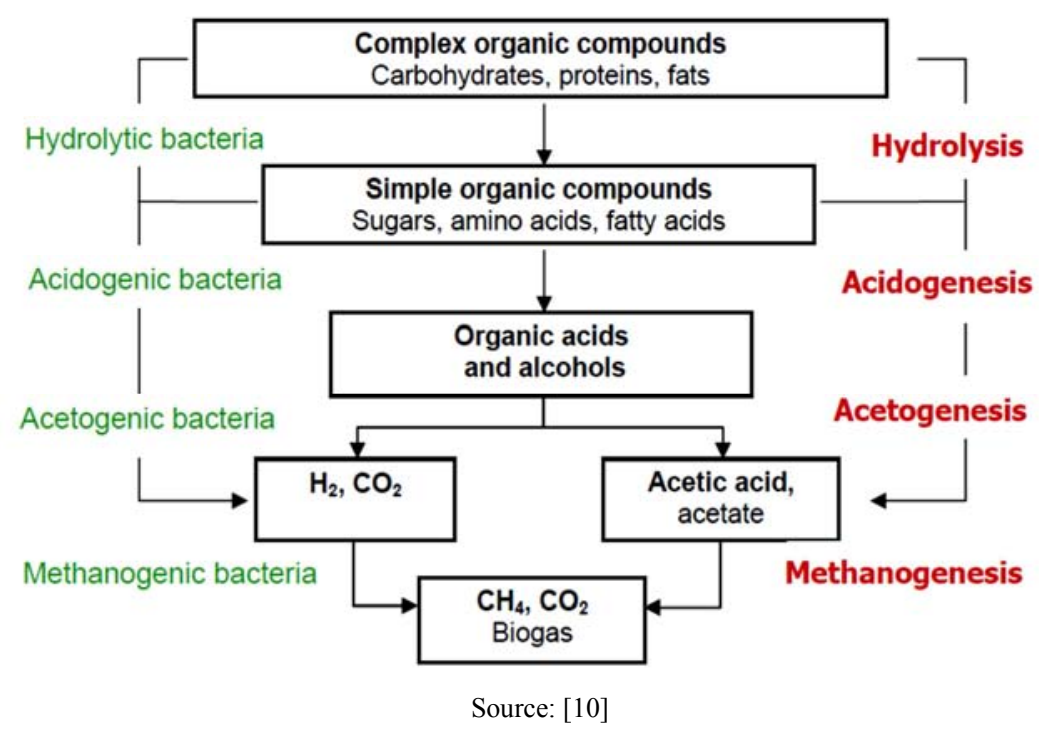

Figure 1. Conversion of fermentation substrate to biogas.

\section{Materials and Methods}

A unique domestic biogas digester was designed and fabricated using locally sourced materials. The design specifications are as follows:

a) 1 × 0.5 bar pressure gauge, limit of measurement is $16 \mathrm{bar}$

b) $1 \mathrm{x} 50$ litres, $2 \mathrm{~mm}$ thick stainless steel drum suitable to act as a digester.

c) $1 \times 1 \mathrm{~mm}$ thick, 0.5 inch diameter gas outlet pipe

d) $1 \times 2 \mathrm{~mm}$ thick, 3 inches diameter discharge pipe

e) $1 \times 2 \mathrm{~mm}$ thick, 5 liters, $20 \mathrm{~cm}$ height premix tank

f) $1 \times 2 \mathrm{~mm}$ thick, 3 inches diameter Influent pipe

g) Sheet metal as a cover over the insulation

h) Various PVC fitting including glue and primer

i) Guttering silicon

j) Various tech screws, screws and other fasteners

k) $1 \times 60 \mathrm{~mm}$ ball valve for solids outlet
1) $1 \times 20 \mathrm{~mm}$ ball valve for gas outlet

m) The compressor used was evaluated as follows:

Maximum compression ratio $=4$

Pressure of biogas in the cylinder $=4$ bar

Pressure of biogas from the digester $=1 \mathrm{bar}$

$$
\begin{aligned}
\mathrm{V}_{1}=\pi D^{2} \mathrm{~h} / 4 & =\pi \times\left(30 \times 10^{-3}\right) \times 0.195 / 4=1.378 \times 10^{-4} \mathrm{~m}^{3}(1) \\
\mathrm{V}_{\mathrm{c}} & =5 \mathrm{~L}=5 \times 10^{-3} \mathrm{~m}^{3} \\
\mathrm{P}_{\mathrm{C}} & =4 \times 101325 \mathrm{~N} / \mathrm{m}^{2} \\
\mathrm{~T}_{\mathrm{C}} & =298 \mathrm{~K}
\end{aligned}
$$

The polytropic process involved in the gas compression is given by Equation [2],

$$
\begin{aligned}
& \mathrm{PV}^{\mathrm{n}}=\text { constant } \\
& \left(\mathrm{p}_{1 /} \mathrm{p}_{2}\right)^{\mathrm{n}}=\mathrm{V}_{2} / \mathrm{V}_{1}
\end{aligned}
$$


$\mathrm{V}_{2}=\left(\mathrm{p}_{1 / \mathrm{p}_{2}}\right)^{1 / \mathrm{n}} \mathrm{V}_{1}=(1 / 4)^{1 / 1.32} \times 1.378 \times 10^{-4}=4.821 \times 10^{-5} \mathrm{~m}^{3}$

Using ideal gas equation,

$$
\mathrm{P}_{\mathrm{C}} \mathrm{V}_{\mathrm{C}}=\mathrm{m}_{\mathrm{C}} \mathrm{RT}_{\mathrm{C}}
$$

Relative molecular mass of methane $=16 \mathrm{~kg} / \mathrm{kmol}$

Thus gas constant $\mathrm{R}$ for biogas $=(8.3145 / 16)=$ $0.5197 \mathrm{Kj} / \mathrm{kg}$

$$
\mathrm{m}_{\mathrm{c}}=\left(5 \times 10^{-3} \times 101325 \times 4\right) / 298 \times 0.5197 \times 10^{3}=13.085 \times 10^{-3} \mathrm{~kg}
$$

$\mathrm{N}_{\mathrm{s}}=$ Number of strokes to fill cylinder to $4 \mathrm{bar}=\mathrm{Vc} / \mathrm{V}_{2}=5 \mathrm{x}$

$$
10^{-3} / 4.821 \times 10^{-5}=104
$$

$$
\begin{gathered}
\text { Work output }=\mathrm{n} / \mathrm{n}-1\left(\mathrm{P}_{2} \mathrm{~V}_{2}-\mathrm{P}_{1} \mathrm{~V}_{1}\right) \\
=1.32 / 0.32\left[\left(4 \times 10^{5} \times 4.821 \times 10^{-5}\right)-\left(1 \times 10^{5} \times 0.1378 \times 10^{-3}\right)\right] \\
=22.704 \mathrm{~J} / \text { cycle }(\text { for one stroke })
\end{gathered}
$$

Thus, total work output to fill cylinder to $4 \mathrm{bar}=22.704 \mathrm{x}$ $104=2361.21 \mathrm{~J}$

The various components listed in association with their joining fittings were used to fabricate the digester. Figure 2 shows the fabricated design

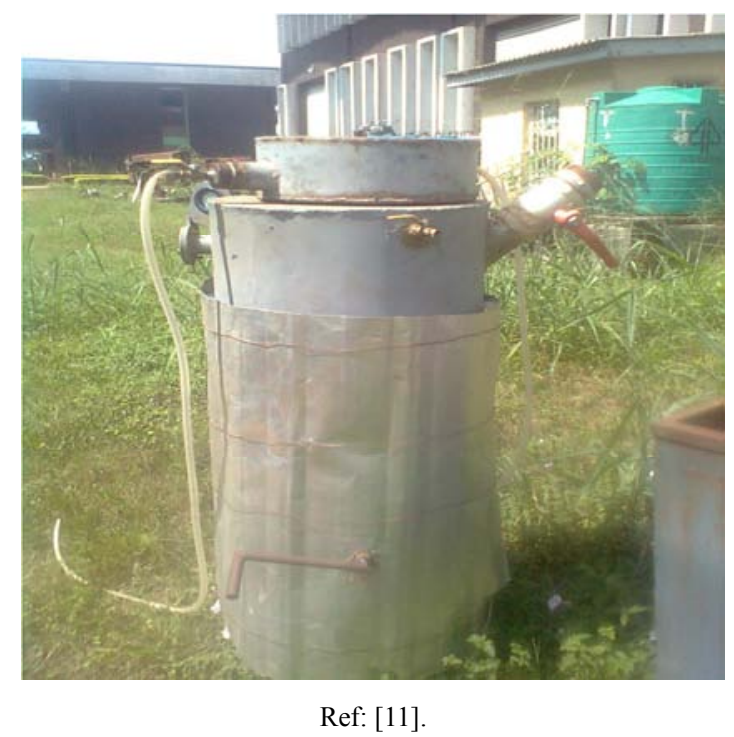

Figure 2. Locally made biogas digester.

\subsection{Cost of Design}

The total cost on fabricating the design (including labour) is shown in Table 1.

Table 1. Cost of fabricating the digester.

\begin{tabular}{ll}
\hline MATERIALS & AMOUNT (N) \\
\hline stainless steel drum & 2500 \\
hose & 500 \\
pressure gauge & 1,500 \\
Sheet metal & 20,000 \\
Stainless steel pipe & 1,500 \\
Compressor & 15,000 \\
Others & 12,000 \\
TOTAL & 53,000 \\
\hline
\end{tabular}

\subsection{Experiment}

A mixture of $20 \mathrm{~kg}$ cow dong, $4 \mathrm{~kg}$ of water hyacinth, and 8 $\mathrm{kg}$ of domestic waste was made into slurry using 30 litres of water fed into the fabricated digester. The following were observed on the fabricated digester:

a. On the first day, little or no gas was produced

b. On the second day, the quantity of gas produced continued to increase and on the sixth day, $0.052 \mathrm{~kg}$ of biogas was extracted into a 4litres storage cylinder at 1.93 bar using the manual compressor.

The gas generated was passed through the drying compartment into the compression chamber from where it was compressed into the gas cylinder.

\section{Results and Discussion}

From experiment, a reasonable amount of biogas began to incubate on the third day of the test period. Biogas production was at its optimum on the $5^{\text {th }}$ and $7^{\text {th }}$ day of the 10 days test period. There was no deflection observed on the pressure gauge of the digester. This indicates that the gas produced was not enough to cause a significant pressure variation in the digester. In comparison with the design calculation, 8 to 13 strokes were enough to transfer the gas produced in the digester. The gas collected burned with a blue flame indicating the presence of a saturated hydrocarbon which in this case is methane.

By converting cow manure into methane biogas via anaerobic digestion, thousands of cattle in Nigeria would be able to produce enough gas to be used by thousands of homes. According to [12], one cow can produce enough manure in one day to generate 3 kilowatt hours of electricity; only 2.4 kilowatt hours of electricity are needed to power a single 100-watt light bulb for one day [1]. Domestic biogas technology is a proven and established technology in many parts of the world, especially in Asia. Several countries in this region have embarked on large-scale programmes on domestic biogas, such as China and India.

\section{Conclusion}

Biogas production will cater for the energy needs of rural homes, urban regions, supply enriched manure and maintain environmental sanitation. This technology serves as a means of ensuring availability of gas at all times for domestic purposes. It will also ensure flexibility of where gas is consumed. A simple domestic biogas digester has been designed and fabricated with locally sourced material. Using a mixture of $20 \mathrm{~kg}$ cow dong, $4 \mathrm{~kg}$ of water hyacinth, and $8 \mathrm{~kg}$ of domestic waste, a reasonable amount of biogas began to incubate on the second day of the test period. However, during the $5^{\text {th }}$ and $7^{\text {th }}$ day of the test period, biogas production was at its peak. The digester should be produced on a mass scale for use rural areas as this will reduce the rate of deforestation, promote clean environment and emit less green house gases. 


\section{Abbreviations}

$\mathrm{V}_{1}=$ Swept volume, $\mathrm{m}^{3}$

$\mathrm{V}_{2}=$ Compressed volume, $\mathrm{m}^{3}$

$\mathrm{V}_{\mathrm{C}}=$ Volume of cylinder, $\mathrm{m}^{3}$

$\mathrm{P}_{\mathrm{c}}=$ Pressure of gas in cylinder $\mathrm{N} / \mathrm{m}^{2}$

$\mathrm{M}_{\mathrm{c}}=$ Mass of gas in cylinder

$\mathrm{T}_{\mathrm{C}}=$ Temperature of gas in cylinder, $\mathrm{K}$

$\mathrm{R}=$ Specific gas constant

$\mathrm{N}_{\mathrm{s}}=$ Number of strokes

\section{References}

[1] Stephen 1. 1 (2010). Biogas utilization. Available at www.ezinearticle.com /article

[2] www.biogas.de/en/technology/what-is-biogas.html Assessed $4^{\text {th }}$ July, 2012

[3] www.euractiv.com/energy/biogas-green-gas-linksdossier369788, Assessed 4th July, 2012.

[4] Comfort O. C (2009). Gender and renewable energy in rural Nigeria. Technical Report, Federal University of Technology, Owerri, Imo State Nigeria.

[5] Chevalier J. M (2006). Energy supply for the European Union. European review energy markets, Vol. 1 pp 22-26.
[6] Opeh R. and Okezie U (2011). The significanceof biogas plants in Nigeria's energy strategy. Journal of Physical Sciences and Innovation,Vol. 3. pp 13-16.

[7] Shawn R. Freitas S and Juan A. S (2011). Development of a gasification system for utilizing fish processing waste and coastal small diameter wood in rural areas. Energy and Fuels Journal,Vol. 25 pp 30-38.

[8] Linghong Z., Chunbao C. X and Pascale C (2010). Overview of recent advances in thermochemical conversion of biomass. Energy conversion and management Journal, Vol. 51 pp45-50.

[9] Obisesan A. (2012). Review of Renewable Energy Sources in Nigeria - Security and Challenges International journal of advanced renewable energy research, Vol. 1. pp145-155.

[10] www.schaumann-bioenergy.eu. Assessed $4^{\text {th }}$ July, 2012.

[11] Abire A. O, Enakerekpo E. Akaeze C. Ikhaobomeh A (2011). Design and fabrication of a biogas digester for domestic use. Technical report, Department of mechanical engineering university of Benin.

[12] Michael E and Amanda D Cuellar (2009). "Cow Power. In the News: Short News Items of Interest to the Scientific Community in United States. 